\title{
ON KNIVES, INFANTIA, AND THE INHUMAN: A LYOTARDIAN READING OF INCENDIES
}

\author{
David Knowles Kennedy ${ }^{1}$ \\ Montclair State University, USA \\ Walter Omar Kohan² \\ State University of Rio de Janeiro/FAPERJ, Brazil
}

\begin{abstract}
This text is an attempt to offer a reading of Incendies, a 2010 Canadian film written and directed by Denis Villeneuve, adapted from Wajdi Mouawad's play of the same name in the light of Lyotard's notion of infantia. From this perspective, we can make a distinction between childhood as a temporal human stage, and infantia as an atemporal human condition: infantia may be described as the difference between what can and can not be said-the unsayable, something lost that inhabits, imperceptibly, the speakable as its shadow, its reminder, an unspoken that works as a condition of possibility in order that something meaningful could be said. As such it is a form of the inhuman, opposed to the other form of the inhuman, called "development," "competition," "representative democracy," "the market," "free world," or simply "capitalism." Lyotard affirms that the political task of literature and art is to remember the former inhuman, the one that each human soul carries by the fact of having been born from a forced need to abandon its condition of indeterminacy. "Political," for Lyotard, is the resistance to the inhumanity of the capitalist order by means of remembering the inhuman from which every order emerges. This is the aesthetic and political strength of Incendies: to present to us, through its heroine, "the woman who sings," an appeal to remember the silenced inhuman from which we come, and which our social life has made us forget.
\end{abstract}

Key words: infantia; J.-F. Lyotard; inhuman; Incendies

\section{Acerca de cuchillos, infantia e inhumano. Una lectura de Incendios en clave de J.-F. Lyotard}

Resumen

Este texto es un intento de ofrecer una lectura de Incendies, una película canadiense escrita y dirigida por Denis Villeneuve, adaptada de la obra de Wajdi Mouawad, a la luz de la noción de infantia de Lyotard. Desde esta perspectiva, hacemos una distinción entre la infancia como etapa temporal de la vida humana e infantia como una condición humana atemporal: a partir de Lyotard, describimos infantia como la diferencia entre lo que se puede y no se puede decir - lo indecible, algo perdido que habita, imperceptiblemente, lo dicho como su sombra, su memoria, algo tácito que funciona como condición de posibilidad para que algo significativo pueda decirse. Como tal, es una forma de lo inhumano, opuesto a otra forma de lo inhumano, llamada "desarrollo", "competencia", "democracia representativa", "mercado", "mundo libre", o simplemente "capitalismo". Lyotard afirma que la tarea política de la

\footnotetext{
${ }^{1}$ E-mail: kennedyd9@verizon.net

2 E-mail: wokohan@gmail.com 
literatura y el arte es recordar esa primera forma de inhuman, que cada alma humana carga consigo por el hecho de haber sido obligada a nacer y abandonar su condición de indeterminación. "Política" para Lyotard, es la resistencia a lo inhumano del orden capitalista por medio de recordar lo inhumano de la que cada orden emerge. Esta es la fuerza estética y política de Incendios: darnos a conocer, a través de su heroína, "la mujer que canta," un llamado a recordar lo inhumano silenciado de dónde venimos y que nuestra vida social nos ha hecho olvidar.

Palabras llave: Incendios, inhumano, infantia, J. F. Lyotard

\section{Sobre facas, infantia, e o inumano: uma leitura lyotardiana de Incendies}

Resumo

Este texto é uma tentativa de oferecer uma leitura de Incendies, um filme canadense de 2010 escrito e dirigido por Denis Villeneuve, adaptado a partir da obra de Wajdi Mouawad, à luz da noção de infantia de J.-F. Lyotard. A partir desta perspectiva, fazemos uma distinção entre a infância como um etapa temporal da vida humana e a infantia como uma condição humana atemporal: infantia pode ser descrita como a diferença entre o que pode e o que não pode ser dito - o indizível, algo perdido que habita, imperceptivelmente, o dizível como sua sombra, o seu lembrete, algo tácito que funciona como uma condição de possibilidade, a fim de que algo significativo possa ser dito. Como tal, é uma forma do inumano, oposta a outra forma de o inumano, chamado de "desenvolvimento", "competição", "democracia representativa", "mercado", "mundo livre", ou simplesmente "capitalismo". Lyotard afirma que a tarefa política da literatura e da arte é lembrar aquele outro desumano, o que cada alma humana carrega pelo fato de ter nascido de uma necessidade, forçada a abandonar sua condição de indeterminação. "Política", para Lyotard, é a resistência ao inumano da ordem capitalista por meio de lembrar esse outro inumano a partir do qual toda ordem emerge. Esta é a força estética e política de Incendies: apresentar a nós, por meio de sua heroína, "a mulher que canta," um apelo para lembrar o desumano silenciado de onde viemos, e que nossa vida social nos fez esquecer.

Palavras-chave: infantia; J.-F. Lyotard; inumano; incêndios 
My theory is that one characteristic of our time is that something is missing, as if we had lost one arm, but as it happens with the amputated, continue to feel it as if it were there. It is a complex feeling because we do not know how to define what it is that is missing today, but something is missing. Through my plays and books I aim to remember and talk about this feeling of lack. Why does it call for so much attention in my work? This I do not know."

W. Mouawad. In: GARFÍAS, 2016

This text has been written with four hands, four eyes, four ears, twenty fingers and a number of other tools from a double body machine affected by the mysteries evoked by Incendies, a 2010 Canadian film written and directed by Denis Villeneuve, adapted from Wajdi Mouawad's play Scorched.

At the very beginning of Incendies we are told, in a letter from a dead woman to her children "Infancy is a knife stuck in the throat. It can't be easily removed," a statement that functions as a question, and further, as a riddle that goads us through the tragic landscape of the film. Our essay is offered as an attempt to unfold some of the possible assumptions and inferences that lurk in this statement, and to trace them through the Cretan Labyrinth of paradoxes, reversals and aporias of the story. Our guides in this task will be Jean-Francois Lyotard's notions of infantia and of what he calls "the inhuman", which will, we hope, provide a red thread that will lead us to the monstrous sanctum of the archetypal Minotaur itself and out again, in the course of one possible reading of the aesthetic and political dimensions of the film.

\section{Childhood/Infancy as a knife in the throat}

The film's opening statement is read from the last will and testament of Nawal Marwan to the fraternal twins Jeanne and Simon Marwan by one Jean Lebel, the Quebecois notary for whom Nawal served as a secretary in the latter half of her mysterious and star-crossed life. Following her enigmatic deathbed directions, Lebel will act as the Charon who will ferry the twins, over the Styx of memory in search of 
their father and their brother, the first of whom they had assumed to be dead in a civil war, and the second of whom they had never seen or heard of until this moment-in search, in short, of their childhood. Narwal's premonitory statement immediately evokes the image of one's childhood as a wound that is inflicted upon one's adulthood--and not just a wound but a wound that will never heal; or, per the second part of the statement, which will not heal until the instrument that inflicted it is somehow, and with difficulty - that is, by way of a process of working through involving some sort of anamnesis--removed. As such, the film challenges us to go a little further, behind or before the conventional notion of "childhood," a behind and before that are neither topical nor chronological but ontological. In other words, our attempt is to move from childhood to infancy, to the very first movement before any human being moves, to the very first birth into being before we are born into earth.

In the case of Incendies, the removal of the instrument that inflicted the wound requires encountering the sublime and numinous terror of our quasi-mythical origins, and by implication the deep origins of what constitutes each of usexpressed in Freudian terminology as the Oedipus myth, sexual difference, castration of the mother, the incest taboo, pregenital sexuality, or in the association of incest with the gods and the semi-divine, as in ancient practices of royalty, or any other formula referring to that very first blow before we turned into ourselves.

The throat is the place in the body where human speech originates, and where the critical difference between infans (not speaking) and adult is most concrete. But it is also the place where infancy speaks without speaking, or beyond speech, an affective state that both indwells and exceeds the body. It cannot be captured by language, for it is before all representation, articulation and delineation, before all construction, education, and socialization. This "before" is not a "life-stage," either of the individual or the species. It cannot be captured or expressed by discursive language. If infancy is a form of the inhuman, a condition and not a stage of human life, then the metaphor of infancy as a knife that wounds our throat that cannot be ("easily") healed suggests both that there is no ("easy") human life without the inhuman, no true life without the primary body and, at the same time, that culture and society are, in a way, unsuccessful attempts to abandon and forget infancy. As 
Lyotard points it out, "the wound we are talking about ... bleeds incessantly, it demands, of course, to be treated, but also not to be treated, [but] to be respected..." (LYOTARD, 1999, p. 52). As we will see, this is the main political dimension of the film: to remind us that there is no possible human life without bleeding or, in more conceptual terms, that a human life worth living demands a certain relationship to infancy, as a form of the inhuman. In this sense, Incendies is a call to live a fully human life-which requires that we treat infancy with respect.

Following Lyotard further, we may also consider that the Law, which cannot tolerate and thus proscribes the infant body, the body ruled by the affect of "immaterial matter," or the "body of aesthesis," attempts to heal this wound to the throat-the original, inchoate center of the human expression of affect. The Law takes the aesthetic body of infancy - that condition of excess, that "remainder" that cannot be assimilated by discursive and representational forms of signification" (LOCKE, 2012)--as criminal flesh that eludes and thwarts Reason. The Law, in its offense at infantia's "criminal innocence" in respect to morals, to the code of good and evil of which it knows nothing, in turn offends the infant body. Like the Harrow in Kafka's story "In the Penal Colony," the Law cuts into the body of aesthesis-pierces it, writing its proscriptions into its very flesh and blood, in the name of the father, of subjectivity itself. It drives infantia into a forgetfulness that is always present, and to which the law owes an unpayable debt. And because infancy is before representation, in wounding it the Law forgets it, even though the very condition of its possibility is the "intractable, the body upon which it enacts itself" (LINDSAY, 1992, p. 393).

By virtue of one of the paradoxical twists in Incendie's narrative, to remove the knife is to "regain" infantia by acknowledging its origins in the inhuman and the sublime, in an experience of pain and pleasure that is before good and evil. Thus Nawal's twins - who are virtually two forms of, one subjectivity--recover, through their memorial journey into the inhuman, their childhood in at least two senses. First, they discover that they were born in the notorious Lebanese prison of Kfar Ryat in a time of vicious, genocidal civil war, in the fifteenth year of their mother's incarceration there in punishment for an assassination of a political figure in the 
Christian-Muslim conflict. The twins were conceived as a result of systematic rape by the infamous torturer "Abou Tarek", who, unbeknownst to either he or Nawal, was in fact her grown son Nihad of May, who had been, as the war lord Chamseddine put it, "swallowed by the war" and ended up serving both sides. Nihad was the product of her first love with a member of the "other side," and was torn from her immediately after birth. In fact her incarceration in Kfar Ryat was the indirect result of her long and fruitless search for him through the war-torn countryside; while his monstrous transformation into a killer and a "torture specialist" was indirectly connected with his search for her With this discovery of their incestuous origins, the twins laid bare the enigmatic wound of infantia, an abject, unresolved condition that endures even beyond the apparent resolution of their quest. As Lyotard will make clear, "there is something that will never be defeated as long as human beings will be born infans, infants. Infantia is the guaranty that there remains an enigma in us, a not easily communicable opacity-that something is left that remains, and that we must bear witness to it." (LYOTARD; LAROCHELLE, 1992, p. 416).

The story of Nawal's "scorched" life and the resolution of the puzzle by the twins also testifies to the enigma of the human condition: that to discover, as adults, our "true" history reveals our debt to the infans of infantia. Jeanne and Simon discover that there is no human order, no social life, no regulative state, no law, no living together in the condition of infantia; but at the same time no aesthetic or political life without the attempt to testify to it.

The apparently nonsensical, riddle-like commands to the twins that Nawal dictates to Jean Lebel on her death bed that initiate their search - to find their father and their brother and deliver two sealed letters to them (actually "him"), - may be interpreted as one form of that testimony. Just prior to her death, Nawal spots hertorturer-who-is-also-her beloved-long-lost-son-who, decades later, has emigrated to Quebec and works as bus cleaner--at a public swimming pool, and recognizes him by three dots on his left heel tattoed there at his birth. He does not recognize her. She collapses, goes silent, and dies shortly afterwards, after dictating to Jean Lebel the two letters of instruction to the twins. Their last task is to hand the sealed letters to 
Nihad of May/Abou Tarek. They intercept him as he enters the lobby of his apartment building, and hand him the two envelopes, one marked "to the father," the other "to the son," then quickly leave. He opens them. The first, addresses her implacable torturer, who had tried unsuccessfully to "break" her in prison through repeated rape. "I recognized you. You didn't recognize me. It's magnificent, a miracle. I am your Number 72 [the number of her cell in Kfar Ryat]. Our children will deliver this. You won't recognize them for they are beautiful. But they know who you are." Upon reading this, Nihad rushes outside in search of his siblings/children,--to kill them as witnesses of his crimes or to embrace them?--but they are gone. The letter finishes, "Through them, I want to tell you that you are still alive. Soon you'll turn silent I know, for all are silent before the truth." It is signed "Whore 72". Then he opens the second letter: "I speak to the son, not to the torturer. Whatever happens, I will always love you. I promised you that when you were born, my son. I looked for you all my life. I found you. You couldn't recognize me. . . . I recognized you, and I found you beautiful. I wrap you in tenderness, my love. Take solace, for nothing means more than being together. You were born of love, so your brother and sister were born of love too. Nothing means more than being together. Nawal Marwan, Prisoner Number 72." Later in his office, their task accomplished, Lebel hands the twins their mother's last letter to them, which informs them that she has fulfilled her promise to "break the chain of anger." "The silence will be broken," she writes, "a promise kept." "My loves, where does your story begin? At your birth? If so, it begins in horror. At the birth of your father? Then it begins in a great love story. But I say your story begins with a promise, to break the chains of anger. Thanks to you, today I have finally kept it. The chain is broken. Finally I can take the time to cradle you, to gently sing a lullaby to console you. Nothing means more than being together. I love you. Your Mother, Nawal." The last shot of the movie shows Nihad standing silently before his mother's grave, as if before a closed door. There is no reconciliation, no possible life together: the debt that the human (adult) owes to the inhuman of infantia cannot be settled, but only remembered-- but that memory will forever invoke a condition that prevailed before there were chains to be broken. 
Jeanne and Simon recover, through their memorial journey into the inhuman, into the powers of horror and the abject, infantia in its present absence as the unboundaried, the unsayable - as a radical ontological condition, an initial inhuman movement from not being to being, an ungrund. They recognize that they are, as adults, in debt to this condition. Do they also grasp that the condition of infans, of "miserable and admirable indetermination," the aesthetic body, the spirituality of flesh, is all that stands in resistance to another form of the inhuman? For this other inhuman-the inhuman of "development" and "complexification," childhood is simply a functional waystation on the adult journey towards a post-human bionic future. But a further clarification of Lyotard's conceptual vocabulary will be necessary to bring his ideas into a full encounter with the film.

\section{Incendies and Lyotard's notion of infantia}

Infantia is a polysemic word in Lyotards' works (LOCKE, 2012). On the one hand, he builds on the Freudian notion of primary narcissism and reinscribes it as a "monstrous" presence in a body that goes beyond anthropomorphic bodies. As such, it is associated with the artistic and the political, as a "zone in which the "work" in the term "work of art" is conveyed through an inaudible gesture that touches and alters temporality. He stretches the borders of the body to include infancy as a zone of pure affect at work inside the art object. This zone mobilizes the capacity to be touched from the outside by that artwork as a sensorial affect." (LOCKE, 2012) In another respect, infantia can be described as the difference between what can and can not be said--the unsayable, something lost that inhabits, imperceptibly, the speakable as its shadow, its reminder, an unspoken that works as a condition of possibility in order that something meaningful could be said.

From Lyotard's perspective, we can make a distinction between childhood as temporal, and infantia as atemporal. Whereas childhood can be removed from a life, infantia is an unavoidable, inescapable dimension of the inhuman that inhabits any human life as its condition, and cannot be removed in any way. It can be remembered or forgotten, but a life without infantia would not be a human life. To understand this distinction problematizes all conventional approaches to the adult- 
child relation--most obviously in the case of conventional educational discourse, in which schooling is implicitly understood as a way to remove or abandon childhood. In the discourses of "child" and "life-span" "development", childhood is understood as a discreet, predictable stage of human life, which in turn is understood as a linear process of successive, consecutive and constant non-reversible evolutionary movement. Here, childhood is removed by "growing up," and the school is the social institution charged with managing this process of removal in as painless a way as possible, and in agreement with the aspirations that support school as a given social and cultural institution. All conventional schools of all times and places share this project: to make the abandonment or removal of childhood painless, and in doing so, to create adult subjects who can function to maintain socially dominant values and aspirations.

Thus, schooling is the cultural road of conversion from childhood to adulthood through the social dispositifs of discipline and control, applied in order (albeit ultimately unsuccessfully) to excise infantia, to forget the ontological ungrund altogether. Functionally speaking, the passage is a transformation of an experience of time--from aion to chronos; of thinking--from questioning to answering; and of being in the world--from play to duty. In the film, Jean Lebel the notary - here in the role of the record-keeper, the master of linearity, the exemplary adult, the servant of chronos and the Law--suggests twice to the reluctant twin Simon that he "grow up". Simon tends to resist, In fact he is already quite "grown up" in his insistence on forgetting, even shunning the inhuman of infantia by avoiding the truth of his origins. It is only his "other self" in the person of his twin sister that draws him closer through the emotional force and the daring tenacity of her search for their father and brother. Only in abandoning the elision of infantia in adult rationality does he in fact grow up. And in doing so, he (and she) become, as Nawal pronounces them, "beautiful," and unrecognizable to the socially constructed adult, who is captive to that other form of the inhuman-the inhuman of capitalism, "growth," complexification and the future cyborg or biorobotic subject.

Real growing up means for Simon-and also for Jeanne--accepting the reality of the impossible, the monstrous: their mother was violated by her son, their 
brother-father. In human life, a brother cannot be a father. Their story is historically and rationally unacceptable, yet they have to accept it in order to live a human life, in order to have a new birth. To grow up means to accept that they are part of a horrifying, inhuman story - a story, as in Greek tragedy, that unfolds beyond their will, or intention, or even consciousness. What in fact will lead Simon to "grow up" in the sense of becoming truly emancipated is not, as we expect to find in ordinary "civilized" life, simply a matter of accepting one's own socially filtered history. Rather, it is a matter of confronting the horror of the abject-the undifferentiated, incestuous, uncanny, dangerous, forbidden, mad, unclean, the object of taboos - an unnamable otherness which is invoked in our own lived origins, which is part of our own history. The abject, as one of the four mathematicians in the story (Nawal, her daughter Jeanne and their respective higher math teachers at university) states--is an "insoluble problem" whose investigation leads to "more insoluble problems," and ultimately founders on the paradox of $1+1=1$ and, as Jeanne's professor Niv Cohen states, can only be solved by "intuition" and "peace of mind." This equation, which dazzles in its uncanny elegance, is finally all that Simon, in his horror and disbelief, can find to say to his sister when it becomes clear that the twins are the children of their brother: father plus brother equals .. ?

As a mathematician cannot accept the aporia of $1+1=1$, a rational and civilized society cannot accept the abject, the irrationality that constitutes this specific form of infancy. It cannot live with the memory of what challenges its own basis. Society feels the need to forget infancy, and neoliberal societies seem to have developed more and more sophisticated dispositifs in order to achieve this aim. In Incendies, the problem is doubled: this "family," if we might call it as such, has had to overcome an difficult and unexpected childhood, and at the same time a silent, unseen but unavoidable infantia, which casts a double shadow. The mother's attempt to solve the double problem is to mirror her internal rupture by splitting-between her son the torturer/rapist and her son the offspring of her first love. They don't know each other. They never will. They cannot be in any form of human relationship. The only moment in which she meets them together, in one naked body in a pool, she cannot connect with this two that is one. For her, they are two, they 
can't be one. She cannot be in any form of human relationship with them, but in her final letters they are reconciled in her affirmation of the inhuman, whose ground turns out to be unconditional love. Nawal's life and her promise to "break the chain of anger" are testimony to the fellowship of all humans in the inhuman, the beforebeing of infantia, a form of being together ("nothing," she writes three times, both to the beloved son and the rapist-torturer, "is more important than being together") in the ungrund, the apeiron that is infancy, the body of aesthesis, the body before the Law, before the Father, before the sexual binary, before the ethical.

There is no family no society, no culture with the abject. In the last minute of the film the killer son (although he no longer kills, but cleans and carries garbage) loses sight of the twins, the offspring of his monstrous urge to violate and destroy; then, as the beloved son, he stands innocent before his mother's grave. The problem has not been solved. The conflict cannot be overcome by "normal" adult reasoningby ethics, law, custom or compensatory justice of any kind. The exceptionality of the mother, consists in that, in her redeeming love, she has incorporated the abject in the form of the impossible one=two; one=father+son; the innocent baby and the sociopathic murderer; life and death; love and hate: all opposites are one in Incendies. No science, no rationality, no social order is possible with them. . "I looked for you all my life," she writes. "I found you. You couldn't recognize me. . . . I recognized you, and I found you beautiful," as she had described the twins in her letter to the torturer. Nihad does not recognize either her or the twins, but she promises him that the revelation of the inhuman in the abject, in infantia that she has brought to him through her revelation of his origins, will re-awaken him: "I want to tell you that you are still alive," she writes. Is this a suggestion that there still is space for transformation, revolution, another form of life?

Although it ultimately kills her, Nawal overcomes the conflict by accepting and even nurturing it. While in prison, she resisted her captors and her torturers by singing constantly in her cell. Those who heard her song could not quite remember it, in spite of its beauty, and she became known in the memory of all whose innocent flesh endured the hell of Kfar Ryat as the "woman who sings". The impossibility of remembering her singing makes us remember what cannot be forgotten: her song is 
the sublime, the impossible expression of the aesthetic body, infantia, the open throat of the inhuman, which we recognize in art and in intractable resistance to that other inhuman, the one that will lead to the cyborg. The "woman who sings" inscribes in us a remainder, a not-communicable opacity that will never be defeated as far as humans are born infants.

When they begin their search the twins are not children and they are not adults, simply because they cannot live in childhood nor in adulthood--they cannot inhabit a human life, they are not humans. They are told that only through searching out the "truth" (the record, as kept by the notaries, the record-keepers, the adults, the society, the law) of their origins will they become adults. But in fact they are not searching for their childhood, they are searching for their original condition--for what makes them human in a deeper sense that the civilized and confortable life of their capitalistic world; in fact, their childhood in civilized, middle-class Canada is perfectly well-remembered and quite "normal," a comfortable life that any reasonable human being would desire to live. They have different ways of confronting the challenge of their origins: while Jeanne is more ready to confront the unavoidable, Simon, perhaps knowing better what lurks ahead, tries to delay the inescapable. He expresses irritation with his mother for her abnormal life. He questions the lawyer. He resists his sister's passionate quest. But finally they both join in undertaking the task of uncovering the abject as an unavoidable dimension of their attempt to live a human life, and it is Simon who finally hears the truth from the Muslim warlord Chamsedinne who was Abu Tarek's commander; nor could it be different in a macho society.

In this moment of truth, we recognize that, as a woman persecuted by violent and impositional patriarchy - Nihad's father, her first and only love, who was from the "other side" of the interminable conflict, was shot at point blank range in an "honor killing" by her cousin. Later, Nawal renounced the violence of the Christian "nationalist" side of the conflict, assassinated the leader of the coalition, and as a result was condemned to 15 years of prison and torture. As such, she was a martyr.

Her cause, however, is behind and beyond politics per se. Her body, violated so systematically in Kfar Ryat, was an aesthetic and political body, a body in which 
the "chain of hatred" forged by the patriarchal lex talionis was broken, but not her. She was there because of her political militancy and because of her aesthetic militancy, as expressed in her courageous descent into the maelstrom of the abject, of horror and murderous indifference, all the while singing the faerie song-strange, inchoate, childlike yet a lullaby--of infantia. She invokes this indomitable strength-invulnerability which is the mark of infantia when she addresses "my son, not the torturer" with the words "I wrap you in tenderness, my love. Take solace ...,"; and to the twins, "Finally I can take the time to cradle you, to gently sing a lullaby to console you. Nothing means more than being together. I love you."

Jeanne and Simon lived a very "normal," "civilized" life until they discovered the truth, but this was a sort of false life. In fact, they "were" humans till they discover the truth. But they were false humans because their childhood was not their true one. This is the paradox embedded deep in the narrative: they cannot but search for a truth that, once discovered, will reveal their monstrous origins. The path toward themselves - what they "really" are--is also an unavoidable path that takes them out of themselves, into what constitutes them as a shadow, a forgotten dimension, a remainder. They are exemplars, in a radical and doubled way, of the human aporia: there is no human life without childhood, but neither is a human life possible without the inhuman of infantia. As they perform their final act on behalf of their mother - the act that will allow her name to appear on her gravestone and her face to be "turned towards the sun" - by handing the "truth" to their brother/father in the form of their mother's letters to him, they have become "adults" by completing the "record," now filed and stamped and signed as "truth." They have excised the abject by incorporating it. The consumerist society will now accept them again in the market to continue their inhuman lives. Their childhood has been legitimated by the Law and redeemed by the administrative order, but they will remain forever in the shadow of infantia.

On the other hand, the notary, the representative of order, while a sympathetic, decent and well-educated character, is an example of the excision of the abject. Jean Lobel heeds the adult taboo, the proscription from allowing the wound of infantia to surface - of "bleeding" - by creating a two-dimensional world of truth, 
in which facts, figures, dates, depositions, signatures, identity cards etc. constitute a bullet-proof universe of simple fact, a positivist's dream. Nothing has to make sense as long as it is recorded - one can have the satisfaction of having excluded insoluble problems. The triumph of the signifier over the signified. The neglecting of infantia.

In Incendies, the abject is further represented by the pervasive brutalized horror of a war situation, here modeled on the real event of the Lebanese Civil War, which lasted for a full 15 years (1975-1990). War is the abject's monstrous manifestation in culture, in history, in politics, in religion--a reign of terror in the name of the fundamental social principle of revenge (GIRARD, 1979), and a sign of terminal human stupefaction. The warlord Chamsedinne who delivers the final truth to Simon, like the mother, like the notary, but in a different way than each, has overcome it by accepting it. He mirrors the notary in his placid dispassion: all that one can say about the manifestation of the demonic is that it happened. But it is no accident that the backdrop for this exploration of the inhuman in infantia should bear its strange fruit amidst the monstrous social atmosphere of genocide, in the complete devaluation of human life, and the reduction of human persons to signs - in this case either "Christian" or "Muslim." We may hypothesize, taking a page from psychoanalytic notions of repression, projection and splitting, that one of the origins of war is in fact the very forgetting of the inhuman, of infantia, of that "miserable and admirable indetermination" that is in fact, as the infant body, wild being, the very seat of our shared humanity, a space that will not relinquish the inherent spirituality and sacred inviolability of flesh. And finally Abu Tarek, the sniper who kills children from a rooftop, the torturer and rapist, the violator of his own maternal flesh, has become a monster because he has lost his mother, and with that his infant body. He has forgotten how to weep, as have his brothers in arms. War is the fantasy of the armored machine body, hybrid excrescence of that future inhuman invoked by Lyotard when he speaks of "development."

\section{The Elision of infantia and the inhuman}

As Lyotard puts it, infantia is a latent condition that is behind every word uttered by any human being, and is itself a form of the inhuman. But what it is the 
inhuman? Lyotard distinguishes two of its forms (LYOTARD, 1991): the inhuman system, called "development," "competition," "representative democracy," "market," "free world," or simply "capitalism"; and the inhuman that each human soul carries by the fact of having been born from a forced need to abandon its condition of indeterminacy. This second form of the inhuman inhabits every human being as the passage from not-being to being. We were all forced to be born; no human being was asked if he or she wanted to come into the world. In this sense we are all born from the inhuman and set on a trajectory towards another inhuman.

These two forms of the inhuman are opposed to each other. Consider, for example, the issue of time. The first inhuman, capitalism, imposes the need to run after time, to make productive use of time; to be efficient and effective in order to follow the extensive, successive, consecutive, and irreversible chronological movements that constitute the preferred systematic image of time. The second does not run behind time, but let's time get lost in nonlinear, polymorphic, intensive, repetitive and complex routes and patterns, searching in a distracted way for lost time, especially that remote time of the abandoned indeterminacy, in a movement in which the past does not always precede the present, and the future does not necessarily succeed it. It is the circular time of eternal return, of cycles, such as the time of the Aymara, of a past that is in front of us in the form of what we can see, and the future is behind us as the unknown (NÚÑEZ, R. E.; SWEETSER, E., 2006).

In subjecting the field of economy to the domination of "development," the inhuman also implicitly enters the field of politics. If the first form of inhuman seeks to impose capital in all its variants as the only triumphant and hegemonic idea, with the logical consequence that there could be no possible alternatives to the system and no other idea is feasible beyond capital itself, Lyotard believes that the only possible authentic politics is in the resistance to this capitalist form of inhumanity in the name of the memory of that other form of the inhuman, the forgotten one, that of a soul that constantly remembers its debt to the inhuman from which it was born. In his words: 
does not cease to be born? -which is to say, with the other inhuman? This debt to childhood is one which we never pay off. But it is enough not to forget it in order to resist it and perhaps, not to be unjust. This is the task of writing, thinking, literature, arts, to venture to bear witness to it. (LYOTARD, 1991, p. 7)

Just don't forget the debt to infancy, in order not to be unjust, affirms Lyotard. Resist the inhumanity of the neoliberal order by remembering the inhumanity from which we are born, as a way of remembering the "inhuman potential for dérèglement, for undoing the instituted rules of acculturating forces" (LINDSAY, 1992, p. 391). The "political" - the politics of the inhuman is then the resistance to the inhumanity of the capitalist order by means of remembering the inhumanity from which every order emerges. It is a kind of resistance to the pretention of any order to perpetuate itself, a resistance carried out by remembering what makes any order possible. Neocapitalist societies do not cease in their pretentions to impose increasing control throughout the planet and even further. In order to do so, they seek to silence any thinking or feeling that might question their universality, normality and naturalness-what, as infantia, might reveal them as arbitrary, artificial, abnormal; what might interrupt their pretense to inevitability. "Just don't forget the debt to childhood so as not to be unfair." We wonder whether there is, in this admonition, the articulation of a political dimension that could inform a possible reading of Incendies? Is the film a testimony to the inhuman of infantia? A reminder of the aporia of human existence, in its double dimension of the impossibility of healing the wound of the monstrous childhood and the silenced infantia? A political resistance to any pretension to the naturalization of human existence?

\section{Is still there a political task?}

If so, we could say that Incendies accomplishes what Lyotard identified as the political task of writing: the testimony to what remains as an enigma in us (LYOTARD; LAROCHELLE, 1992, p. 416). But this "political task of writing" may be both necessary and impossible: impossible because we write to give form to both a childhood and an infancy that cannot be written; necessary as a political task - as a crucial affirmation and remembrance of that form of the inhuman that is silenced, denied by the dominant form of the inhuman that drives consumerism, capitalism, 
and neoliberal forms of social order. If writing (or filming) in testimony to infantia is necessary and impossible, so is humanity, so is philosophy - which, like childhood, is a kind of survivor, an entity that should be dead but is still alive (Lyotard, 1997, p. 63). This is probably the aesthetic and political strength of the film: to present to us, through the woman who sings, who cannot be broken because she can love even the abyss, an appeal to remember the silenced inhuman from which we come, and which our social life has caused us to forget.

As a survivor, infantia is also a hope, in Lyotard's words, of "the event of a possible radical change in the flow that pushes things to repeat the same" (LYOTARD, 1997, p. 62). Infantia names something that "already is" but yet is not "something"--a kind of astonishment that inaugurates the world of the human yet cannot be identified. Infantia is the name for a miracle, the interruption of the being of things by the entrance of its other, the other of being. It might be enough not to forget infantia "in order to resist it and, perhaps, not to be unjust," Lyotard says. Might it be enough? Is the feeling of infantia the "something" that "is missing" in our time, according to Mouawad? (GARFÍAS, 2016). Might it, for example, help us conceive of two kinds of political relationships to bodies--the law (old or new) which wrongs the body on the one hand, but on the other a form of life that would respect the "time of the body"? But at the very last, has this essay/assay helped any of its readers not to forget infantia, as our social contemporary dispositifs in neoliberal societies so relentlessly encourage us to do? If so, might we not consider this form of resistance our main political task as writers? We are not sure. In light of the multiple forms that childhood takes in our time, it might not seem to be enough, but who knows, it might be a beginning. A reader sensible to childhood and infantia will certainly help us think about it.

\section{Bibliographical References}

GARFIAS, Ericka Montaño. Necesito oscuridad y misterio para mi obra, pues no sé divertir: Wajdi Mouawad. La Jornada. 19 nov. 2014. Disponível em: $<$ http://www.jornada.unam.mx/2014/11/19/cultura/a06n1cul>. Access in June 12th, 2016. 
GIRARD, Renee. Violence and the Sacred. Baltimore: Johns Hopkins University Press, 1979.

LINDSAY, Cecile. Corporality, Ethics, Experimentation. Lyotard in the Eighties. Philosophy Today, v. 36, n. 4, Winter 1992, p. 389-401.

LOCKE, Kirsten. Lyotard's Infancy. A Debt that Persists. Postmodern Culture. v. 23, n. 1, Set. 2012. p.

LYOTARD, Jean-François. "Before the Law, After the Law: An Interview with Jean François Lyotard Conducted by Elisabeth Weber." Qui Parle. v. 11, n. 2, 1999, p. 3758.

Lecturas de infancia. Buenos Aires: EUDEBA, 1997.

The Inhuman: Reflections on Time. Trans. Geoffrey Bennington and Rachel Bowlby. Stanford CA: Stanford University Press, 1991.

LYOTARD, Jean-François; LAROCHELLE, Gilbert. "That which resists after all”. Philosophy Today. v. 36, n. 4, Winter 1992, p. 402-417.

NÚÑEZ, Rafael E.; SWEETSER, Eve. "With the Future Behind Them: Convergent Evidence From Aymara Language and Gesture in the Crosslinguistic Comparison of Spatial Construals of Time", Cognitive Science. v. 30, 2006, p. 1-49.

Received in: 15.05.2016

Accepted in: 15.06.2016 